This is the peer reviewed version of the following article: Honey-Rosés, J., Maurer, M., Ramírez, M. I., \& Corbera, E. Quantifying active and passive restoration in central Mexico from 1986-2012: Assessing the evidence of a forest transition. Restoration Ecology, which has been published in final form at https://doi.org/10.1111/rec.12703. This article may be used for non-commercial purposes in accordance with Wiley Terms and Conditions for Self-Archiving.

\title{
Quantifying active and passive reforestation in central Mexico from 1986-2012: Assessing the evidence of a forest transition
}

Running Head: Active and passive reforestation

\author{
Jordi Honey-Rosés*1 ${ }^{1}$, Marlene Maurer ${ }^{2}$, M.Isabel Ramírez ${ }^{3}$, Esteve Corbera ${ }^{2}$ \\ ${ }^{1}$ University of British Columbia, Vancouver, Canada \\ ${ }^{2}$ Universitat Autònoma de Barcelona, Bella Terra, Spain \\ ${ }^{3}$ Universidad Nacional Autonoma de México, Morelia, México \\ * Corresponding Author: jhoney@mail.ubc.ca
}

\section{Author contributions}

JHR conceived of the research; JHR, MM, IR, EC designed the research; MM, IR collected the data; JHR, MM, IR, EC analysed the data, and wrote the manuscript.

\section{ABSTRACT}

Recent land cover analysis reveals significant forest recovery around the world, suggesting that some countries may be in a forest transition. However remotely sensed imagery does not reveal the driving causes of forest recovery, which may be due to active reforestation efforts or natural successional processes (passive reforestation). We aimed to distinguish these two processes in the priority temperate forests surrounding the Monarch Butterfly Biosphere Reserve (342 $773 \mathrm{ha}$ ) in central Mexico. We combine an analysis of remotely sensed imagery with field interviews $(n=43)$ to examine the mechanisms and drivers of observed forest recovery. Our analysis of the satellite imagery revealed a net increase of 3798 ha of forest between 1986 and 2012, yet the rate of recovery is slowing. Our interview data revealed that the vast majority of the recovered forests are the result of natural regrowth (passive reforestation), and most of this regrowth is observed on degraded forests. We estimate that between 58 and 429 ha have been recovered from active reforestation efforts in the 19862012 period. We find that reduced logging and grazing pressures are important drivers of forest recovery, while agricultural abandonment may be less influential than often believed. Our results suggest that reforestation investments might be wisely spent supporting and maintaining the natural resilience of forests rather than on costly reforestation programs.

Keywords: forest recovery; forest transition; land use change; Mexico; passive reforestation; restoration

\section{Implications for Practice}

- Cost-effectiveness may be a major constraint to scaling up active reforestation, as suggested by its small contribution to the observed forest regrowth;

- Degraded forests should be considered environmental assets in forest restoration programs, given its significant contribution to forest recovery; 
- Whenever site, landscape and social environments allow for passive restoration, forest restoration programs should consider supporting, facilitating or accelerating natural regrowth instead of active reforestation.

\section{Introduction}

Forest ecosystems cover approximately one third of the planet's land area, and harbour the most biologically rich and genetically diverse ecosystems on Earth (Köhl et al. 2015). While deforestation still is one of the dominating land cover changes around the globe, recent assessments show that the net rate of forest loss has fallen by half (Keenan et al. 2015). Furthermore, forest cover has increased in 18 countries, including in the tropics, where deforestation rates remain high (idem). Reduced deforestation rates are welcome news for countries aiming to protect and restore forests. Increasingly, countries are devoting more attention to forest restoration, as demonstrated by ambitious pledges like Brazil's Atlantic Forest Restoration Pact or 21 African countries' Forest Landscape Restoration Initiative, both under the umbrella of the broader Bonn Challenge Restoration Initiative (Verdone \& Seidl 2017). These efforts are regarded as key mitigation measures to address climate change and improve rural livelihoods.

Considerable resources are being invested or pledged toward forest recovery. For example, in 2011, the European Investment Bank approved EUR 1.3 billion in loans to finance reforestation projects around the world (EIB 2012). India's recently pledged USD 6 billion in reforestation and its massive afforestation project of almost 50 million planted trees in a day made global headlines (Howard 2016). Reforestation projects are popular with political leaders because they can be easily communicated to the public and promise tangible outcomes. They are feel-good programs that may garner strong public support due to a clear link between the donation and the activity that will take place. For these same reasons, nonprofit organisations and global corporations often support reforestation programs. 
Remote sensing data and satellite imagery can help us identify when and where forests are recovered (Van Den Hoek et al. 2014; Walsh et al. 2008). Yet understanding why and how these areas recover remains elusive (Chazdon 2008). The precise mechanisms and processes that explain why these forests are coming back are poorly understood and contested. To begin with, few studies explicitly distinguish between active reforestation and passive restoration (FAO 2013). Studies focus either on the drivers and impacts of natural successional processes (Aide et al. 2013; Sitzia et al. 2010) or the impact and success rates of active reforestation programs, such as human-induced plantations (Payn et al. 2015; Trac et al. 2007). In this paper, we use the term passive restoration, passive reforestation and natural regrowth to refer to forested areas recovered as a result of successional processes and active reforestation to describe forests recovered through tree planting.

Researchers have proposed various hypotheses to explain global trends in forest recovery. Biophysical factors such as climate, elevation, soil and slope tend to be associated with the probability and speed of forest regrowth (Aide et al. 2013; Bonilla-Moheno et al. 2012; Yackulic et al. 2011), but these factors are difficult to control through policy. Crk and colleagues (2009) suggest that natural regrowth may be dependent both on biophysical and socio-economic conditions. In this regard, agricultural abandonment is the most frequently cited socio-economic driver of natural forest regrowth, and generally occurs on lands with low productivity or in communities with widespread rural-urban migration (Aide et al. 2013; Bonilla-Moheno et al. 2012; Crk et al. 2009; Lamb et al. 2005; López et al. 2006; Rudel et al. 2005; Yackulic et al. 2011).

Forest transition theory predicts that forest regrowth will be observed on abandoned lands when countries industrialize and employment opportunities in urban centres attract farmers who abandon their agricultural fields for non-farm jobs (Barbier et al. 2010; Mather 1992; Meyfroidt \& Lambin 2011). Yet while forest transition theory is well established in 
developed countries, such as the United States, it remains unclear if and how tropical countries might go through the same process. A study of eleven developing countries undergoing a forest transition suggests that the observed increase in forest cover in six of these countries has been offset by land-use change and wood imports from other countries (Meyfroidt et al. 2010). Focusing on Jamaica alone, (Timms et al. 2013) argue that Jamaica is experiencing a forest transition, not as a result of an industrializing economy, but of exogenous international policies that are decimating its agricultural sector and generating poverty and rural abandonment.

The existence of forest transitions and the analysis of its drivers and consequences is a policy relevant question for tropical countries, with implications for local development, biodiversity and climate policies. For example, a forest transition would imply a positive trending baseline for forest cover, suggesting that forests would be recovered through structural changes in the economy, regardless of any specific restoration policy. The financial implication of a positive baseline would be a reduced level of potential international payments for Reduced Emissions from Deforestation and Forest Degradation (REDD), but also an increase in a country's ability to minimize the level of greenhouse emissions in the land-use sector and to meet its Intended Nationally Determined Contributions to the UNFCCC.

In many respects, one would expect Mexico to be the ideal place in which to observe a forest transition (Klooster 2003). In comparison to other tropical countries, Mexico is well developed and has a strong economy. Satellite data shows us that fifty per cent of Mexico's forests are secondary (Hansen et al. 2013), suggesting that substantial forest recovery may be underway. However, forest transition theory in Mexico is complicated and confounded by several processes occurring simultaneously. For example, in the southern states of Mexico, the expansion of agricultural and cattle ranching activities co-exists with forest recovery 
driven by reduced agricultural activities or out-migration (Vaca et al. 2012). Similarly, a case study in the Patzcuaro region of central Mexico suggests an uneven forest transition. These communities clearly shifted their income sources away from agriculture, and at the time of the study, only $3 \%$ of households relied on agriculture as their main economic activity (Klooster 2003). Instead, most households received their income from craft production, petty commerce, sporadic wage labor and remittances. While farming had become secondary in nature, forest degradation continued, in part due to fuel wood collection to fire the kilns to make pottery and crafts sold to tourists.

Aside from forest transitions theory, scholars have examined other factors that may explain forest recovery, including drivers that may explain active reforestation. Dependence on forest products (Le et al. 2012; Nagendra 2007), population density (Aide et al. 2013; Nagendra 2007; Yackulic et al. 2011), and tenure regulations (Nagendra 2007) have been used to explain the success of active reforestation measures. Yet studies that examine and compare the relative contribution of passive restoration versus active reforestation are rare (Meyfroidt \& Lambin 2011) but crucial to design practical and cost-effective policies. Understanding the driving forces behind both can help to prioritize investments, increase impact, improve efficiency and save valuable resources. If an area is already experiencing natural forest regrowth due to successional processes, this would indicate to conservation managers how restoration funds might be most wisely used.

Focusing in the region surrounding the Monarch Butterfly Biosphere Reserve in central Mexico, this research has four aims: (1) to quantify the percentage of observed forest recovery that can be attributed to either active reforestation or passive restoration; (2) to identify the main drivers of the respective forest recovery processes; (3) to explain how these drivers influence active and natural recovery outcomes and (4) to provide some insight on the question of forest transitions. 


\section{Methods}

\section{The Monarch Butterfly Biosphere Reserve}

We examined the dynamics of forest recovery in the region of the Monarch Butterfly Biosphere Reserve (MBBR) in central Mexico. The forests of the MBBR are biologically significant because they provide a unique habitat for one of the world's most fascinating and widely studied migratory insects, the monarch butterfly (Danaus plexippus Linn.) (Brower 1996). The forests of the monarch butterfly were first protected in 1980, with subsequent revisions of the protected area boundaries in 1986 and 2000. Most of the forests in the protected area are collectively owned and managed by ejidos or indigenous communities, with the exception of a few private and federal and state properties (Navarrete et al. 2011). The protected area imposes management restrictions limiting forest uses and extraction volumes (Honey-Rosés et al. 2009).

Existing studies on forest cover in the region focus on forest loss and degradation (Brower et al. 2002; Ramírez et al 2003; Vidal et al. 2014) often in connection with legal timber harvests (Navarrete et al. 2011) or illegal extraction (Honey-Rosés 2009). Other studies examine the effectiveness of the protected area, community institutions, or government programs in maintaining forest cover (Honey-Rosés et al. 2011; Nagendra 2008; Tucker 2004), but studies focusing exclusively on forest recovery are absent.

As elsewhere in the tropics, we observe a measurable increase in forest cover in our study area. Yet it is unclear if this forest recovery is the result of active reforestation programs or passive restoration. The MBBR receives considerable funding from international and national organisations to develop reforestation programs (Venegas Pérez et al. 2011). Between 2002 and 2010, the region received an influx of USD \$9.2 million for reforestation programs (SEMARNAT 2011). This calculation does not include donations and grants channelled through international non-profits or foundations such as the World Wildlife Fund 
(WWF) or the Monarch Butterfly Fund (MBF) which would be in addition, since both organizations have active reforestation programs

\section{Data collection and analysis}

We examined forest recovery at three scales: the regional, municipal and plot-level. The regional level consists of the entire protected area and the surrounding municipalities $(\mathrm{N}=24)$ encompassing 342773 ha (Figure 1). At this scale, we analyzed trends in forest recovery with visually interpreted Landsat images from 1986 to 2012 (Ramírez et al. 2006; Ramírez et al. 2015). We categorized land uses and canopy coverage to identify degraded or recovered forests. In this region of Mexico, remote sensing classifications correlate well with a range of measures including basal area, tree density, canopy cover and tree height (Lomelí Jiménez et al. 2017).

We identified sites in which forest had been recovered in six time periods, two prior to the revision of the protected area boundaries in 2000 (1986-1993 \& 1993-2000) and four periods post-protection (2000-2003; 2003-2006; 2006-2009; 2009-2012). The high temporal resolution allows us to identify with greater precision when the forest recovery took place and provides historic land use information. We used land cover maps generated using a systematic method based on visual interpretation (FAO 1996) of multiresolution imagery and high-resolution photographs, as well as field validation of imagery observations (Ramírez et al. 2007). We used Landsat TM $(1986,1993)$ and ETM + imagery $(2000,2003,2006,2009$, 2012), all path/row 27/46-47, $28.5 \mathrm{~m}$ resolution and from the dry season (January to March). Each delineated polygon was simultaneously verified using 1-2 m resolution digital aerial photographs (1983, 1994, 1999, 2001 and 2003) and high-resolution imagery (Ikonos 2004, Aster 2006, SPOT 2009 and 2012, and GeoEye 2010). We carried out on-screen visual interpretation using different versions of ESRI software (ArcView and ArcGIS) for each map 
in our series at the interpretation scale of of 1:40 000, with a minimum mapping unit of 0.8 ha (>9 Landsat pixels).

We categorized areas as recovered forests when the sites became forests from nonforest land covers (grassland, crops, orchards and barren ground) or when secondary shrubs and degraded forests gained canopy density (canopy cover 40-70\%, and $>70 \%$, respectively). Forest recovery detected in a specific period may have been the result of a recovery process that started few years earlier. The two primary tree species of the region, Pinus pseudostrobus and Abies religiosa, benefit from canopy gaps and may reach a height of 3-7 $\mathrm{m}$ in only five years (Espinosa 2006, Lara-González et al. 2009, González Méndez et al. 2016), creating a canopy cover identified as forest in remotely sensed images.

\section{Plot Selection for Interviews}

Our examination identified 550 recovered forest plots in the study region, making it excessively arduous to obtain qualitative interview data for every plot. We therefore chose to focus our field interviews on four municipalities: Angangueo, Aporo, Senguio and Maravatío, which collectively included 146 plots of recovered forests. We aimed to select a balanced and representative set of municipalities with land inside and outside the protected area (Figure 1). By examining forest plots in a diverse range of municipalities, we aimed to select a broader range of ecosystem types, elevations and status of ecological protection that may be more representative of forest recovery in similar ecosystems throughout Mexico.

We categorized the 146 reforested plots in our municipal study area according to three features: size (small < 10 ha; medium 10-30 ha; large > 30 ha), prior land-use (agriculture/pastures; degraded forest) and ownership type (communal; private property). We selected 15 recovered forest plots per municipality (60 total) aiming for a representative sample according to size, prior land-use and ownership type. This selection strategy allowed 
us to target a balanced subset of recovered forest plots. We produced maps of each selected forest plot to orient our field-work, and provide a visual aid during the interviews.

\section{Interview Procedure}

We conducted 43 interviews with forest plot owners from 23 communities in the four selected municipalities between May and June 2016 (Maurer 2016). We also interviewed six individuals from government institutions and non-profit organisations. With the recovered plots being our unit of analysis, our primary selection criteria for interviewees was their knowledge and connection to each individual plot. The interviews allowed us to assess 44 reforested plots covering 789.5 ha, or $45 \%$ of the recovered forests in the four selected municipalities.

We aimed to speak with individuals who owned or managed the selected forest plots, or who were sufficiently knowledgeable about the area to describe the dynamics of forest recovery. To establish local contact, we first visited municipal officials to obtain contact information for elected community leaders (comisarios) and other community officials. After this, we presented the project's intention and scope to the current community leaders to establish trust and request permission to conduct interviews. When available, we compared our maps to the ejidal property plan to accurately identify the owner or stewardship of the selected plot at the time of recovery. Even though forests are usually owned and managed collectively, some individuals held the rights to cultivate agricultural parcels within the community forest. In these cases, we aimed to interview the individual land managers or their relatives. Additionally, we visited recovered plots when possible.

We conducted semi-structured interviews in Spanish that asked about (i) the dynamics of forest recovery i.e. if it was active reforestation or natural regrowth (ii) drivers influencing respective recovery type, (iii) prior land uses, (iv) availability of and interest in reforestation programs, and (v) economic, productive and social changes of the last three decades. We 
requested consent to conduct the interviews, and they were recorded (when permitted), transcribed, translated, coded and analysed. The interviews were coded by one author to avoid discrepancies between several coders. The codes responded to the initial cause of deforestation, the primary reason for forest recovery, and the underlying causes of forest recovery, which included several tiers of sub-codes encompassing a total of 35 codes and sub-codes. We classified plots by size and prior land-use agricultural plot or (b) degraded forest; and then further by forest recovery type (1) active reforestation, (2) passive reforestation and (3) mix of active and passive reforestation.

\section{Quantitative Analysis}

We examined correlations between our primary outcome variable of interest, forest recovery type and plot area, prior land use, and the described drivers of reforestation. We performed an Analysis of the Variances (ANOVA) to test for statistical significance between reforestation types. We also used an ordinal logit regression model to understand the relationship between the reforestation type (active reforestation, mixed and passive reforestation) and the explanatory variables (plot size, protection status (core, buffer and outside) and prior land use (agriculture, barren degraded forest, degraded forest + grazing, degraded forest + fire, and fire)). We used an ordinal logit model because there is a clear sequence in the three reforestation outcomes (active, mixed and passive). The model outputs use the buffer zone and agricultural areas as the reference conditions. Lastly, we estimated how much of the observed forest recovery in our regional study area was likely to be the result of active reforestation. 


\section{Results}

\section{Quantification of active reforestation and natural regrowth}

The analysis of the satellite images reveals a gross increase of forest cover of 5673 ha between 1986 and 2012 within the regional study area. Since some recovered areas are lost during the study period, we observe a net forest recovery of 3798 ha during this period. In net terms, this is a recovery of $1.1 \%$ over the 26 -year period. The four municipalities examined with qualitative interviews account for 30.6\% (1 736 ha) of the gross forest recovery. An overwhelming majority of the forest recovery $81 \%$ (4 593 ha) occurred in the two early periods pre-2000, while only 19\% (1 078 ha) of forests were recovered post-2000. Our sampled municipalities show an even clearer distinction between pre and post 2000 recovery, with $89 \%$ (1 549 ha) of the reforested areas from 1986 to 2000 and only $11 \%$ (186 ha) between 2000 and 2012.

Our interviews revealed that $71.7 \%$ of the surveyed forest area (28 of 44 plots) recovered due to natural successional processes, as opposed to active reforestation (Table 1). They also revealed that 10 forest plots recovered due to a combination of active reforestation and natural regrowth. This mix of active reforestation plus natural regrowth was attributed to several medium and large plots (>10 ha) that varied in terrain characteristics such as slope, soil and accessibility (Maurer, 2016). Accounting for $24.5 \%$ of the assessed forest growth, the category of mixed plots is significant. Finally, only 6 of the 44 sampled plots were recovered due to active reforestation efforts. These sites were small, with an average size of five hectares per plot. We find active reforestation only accounts for $3.8 \%$ of the total increase in forest area within the surveyed plots.

Several patterns emerge when analysing the characteristics of recovered forest plots. Active reforestation is only observed on small plots $(<10 \mathrm{ha})$, while natural forest regrowth occurs on plots of all sizes (Figure 2). Actively reforested plots were small, ranging from 1.9 
to 8.9 ha, with a mean of 5 ha. In contrast, areas of natural regrowth were considerably larger, ranging from 3.8 to 132 ha with a mean of 20.2 ha.

\section{Estimated regional forest regrowth}

We estimate the number of hectares that may have been recovered due to active reforestation programs for the region by extrapolating the observed pattern from our sample. We did not observe any active reforestation on plots larger than 10 ha (Figure 2). This is consistent with the logistical and physical difficulties of reforesting large areas. Therefore we assume that only forest plots smaller than 10 ha are likely to have been actively reforested. For the region, we estimate that active reforestation may have contributed to the recovery of between 58 ha and 429 ha from 1986 and 2012. The range is determined by how much of the "mixed" category is attributed to active reforestation, with the upper estimate assuming that all the "mixed" plots were due to active reforestation programs and the lower bound only using the proportion of plots that were clearly the result of active reforestation.

\section{Prior land use}

Examining the prior land use of the recovered forest plots revealed notable patterns (Figure 3). We observe that natural regrowth is observed on all land use categories except for barren lands. Most notably, forest plots with natural regrowth overwhelmingly come from degraded forests. This is unsurprising since we would expect tree growth and canopy closure to be observed on thinned or degraded forests.

The mixed category describes areas where we find some evidence of active reforestation efforts, but that it is likely that natural recovery played a role as well. In this category, the dominant prior land use was some combination of degraded forests and former 
agricultural lands. Active reforestation sites are predominately on former agricultural lands, with only a small part on degraded forests.

\section{ANOVA and Ordinal Logit Regression}

While there appear to be patterns between reforestation type, size and prior land use, these relationships are not strong enough to be statistically significant in most of the statistical models we ran. The ANOVA model relating reforestation type, plot size and prior land use did not find statistically significant relationships. This is probably explained by the small number of observations in the active reforestation group (6), and the number of plots recovered due to natural forest regrowth that were also small (13). In short, active reforestation plots tend to be small, but this may also be true with forest plots recovered by natural processes. Similarly, the ordinal logit regression model produced statistically significant results only for the coefficient degraded forests while the remaining variables were not found to be significant (Table 2). The absence of significance does not mean that these relationships do not exist, but may be explained by the limited number of observations.

\section{Reported drivers of forest recovery}

The interviews revealed four main drivers of forest recovery: agricultural abandonment, reduced grazing activities, reduced logging, and post-fire recovery (Table 3). Interviewees frequently noted other factors such as urban to rural migration, which we included as part of agricultural abandonment. This categorization merely aims to summarize the primary drivers as described by the land-owners, not necessarily encompass all factors that contributed to forest recovery. 
The interviews provided information that cannot be captured through remotely sensed imagery that helps explain forest recovery. For example, interviewees noted that forest recovery in degraded forests might be the result of three different processes: reduced logging pressure, reduced grazing pressure or post-fire recovery. Land-owners reported that agricultural abandonment contributed to the recovery of 209.3 ha or $26.5 \%$ of the forest regrowth in the surveyed plots. This includes secondary causes for agricultural abandonment, such as migration, which accounted for 77 ha, according to our interviews. A decrease in grazing and logging pressures led to the regrowth of 195 ha and 164 ha of degraded forests respectively, accounting for $25 \%$ and $21 \%$ of the canopy increase in our examined plots. The occurrence of forest fires accelerated a recovery of 184.4 ha contributing $23 \%$ to the detected forest regrowth among surveyed plots. In the following sections, we describe the findings from the interviews in more detail and organize the discussion by the two main reforestation types.

\section{Natural regrowth}

Interviews reveal that forest owners are acutely aware of the forest's capacity to recover though successional processes. The interviewees did not seem to attribute any natural regrowth to the establishment of the protected area. Rather, the interviewees suggested that new agricultural practices that began in the late 1980s contributed to the acceleration of natural forest regrowth. In some areas, agro machinery replaced traditional and animal powered ploughs which led to a decrease in livestock per capita. For safety reasons, and to save labour costs, the remaining livestock were kept in permanent enclosures, which allowed forests to recover where pastoral activities previously inhibited successional processes. Most individuals interviewed (41 of 43) reported migratory tendencies to have been strongest from the mid-1980s until 2000. Driven by lack of economic opportunities, many residents migrated 
from central Mexico to other parts of the country or the United States (García \& Ortega 2015). Furthermore, by the early 1990s many communities observed a significant decrease of legal timber harvesting. "The extraction [of wood] stopped because there was barely anything left", noted one municipal official.

Several individuals described how successional processes are especially fast and strong following forest fires. Interviewees from the communities of Hervidero y Plancha, Aporo, Arroyo Seco and Tupataro recalled cases where fires had destroyed forests but these areas recovered quickly. Hervidero y Plancha and Arroyo Seco both took active reforestation measures after the forest fires to assist recovery but locals stated that the natural regrowth far exceeded the growth of planted trees.

\section{Active reforestation}

We found that forest landowners were motivated to participate in reforestation programs, but also encouraged to reforest by programs, laws, regulations, or the expected financial returns from forest products. The potential of forests to generate income was considered an important driver in the decision to reforest degraded forest plots or reconvert agricultural parcels. Many landowners interviewed rely on subsistence agriculture and have limited sources of income. The low productivity of the land and high fertilizer costs often render the cultivation of corn and other crops unviable. As a result, the conversion of agricultural fields into forests becomes attractive. One farmer from Senguio stated: "people don't want to cultivate their plots anymore. It is not worth the effort and investment. They reforest it to have at least some benefit from it".

While poor economic returns to agriculture seemed to be a strong motivation to reforest, we only encountered three instances where plot owners reconverted agricultural lands to forest. In part, this may be explained by community rules that provide a disincentive 
to reforest an agricultural plot. In most communities in Mexico, households have full control over agricultural parcels, while forested areas are managed collectively (Klooster 2003), thereby providing an incentive to maintain the plot as agriculture, unless a specific arrangement can be made with the community when the lands are converted back to forests. The remaining cases where active reforestation on former agricultural land had taken place were explained by a serious illness, death or permanent migration, in which case the community decided to reforest.

Those interviewed also expressed concern about the success of active reforestation programs, especially in comparison to natural regrowth. Forty of 43 plot owners perceived natural regrowth to be superior to active reforestation in terms of speed, survival rate and overall strength. Interviewees estimated that only $30-50 \%$ of planted saplings survived due to poor planting techniques, inappropriate timing or site location. In contrast, interviewees cited that the acclimation to soil and climate conditions as the fundamental advantage of natural regrowth. With seed availability as the crucial prerequisite, interviewees reported that successional processes were found to take over rapidly on former agricultural plots and degraded forests alike.

Those interviewed suggested that a major generational turnover is expected in the near future. Plot cultivation was mostly carried out by farmers of advanced age $(>60)$ who had worked their lands their entire lives. The abandonment of subsistence agriculture by the youth was a reoccurring theme amongst those interviewed. Youth are more likely to seek opportunities and employment in urban areas. Yet while most migrants are young, as nonland owners without ejido rights, their migration might not directly affect land or forest use. The impact of this migration as a driver for active reforestation becomes apparent in the land owner's decision process whether or not to reforest. The investment of money and labour into 
the active reforestation of one's parcel appears useless if the next generation is not staying to benefit from the forest. Many elderly landowners therefore chose not to reforest their lands.

Most active reforestation efforts are driven by reforestation programs. A multitude of governmental and private organisations engage communities in active reforestation programs in and around the MBBR, the most important being the MBBR itself, broader governmental programs through CONAFOR and COFOM, and organisations as the WWF and the Monarch Butterfly Fund. While communities located in proximity to the MBBR have access to multiple reforestation programs, communities further from the MBBR, especially in Maravatío have difficulty entering into official reforestation programs. Without access to a reforestation program, that will at least provide trees and potentially cover labour costs of planting, communities cannot afford to reforest.

Laws and regulations also may influence communities' decisions to reforest. Communities may aim to meet specific annual reforestation quotas demanded by their own ejidal constitution, the national forestry law or a specific reforestation program which they entered. As a result, active reforestation is driven by the need to satisfy planting quotas, with little genuine interest in the reforestation outcome. The coordination between the different reforestation programs is poor, resulting in communities entering simultaneously in several programs and having to satisfy unrealistically high quotas. While the quotas were initially created to offset the effect of logging and to promote sustainable forest growth, these reforestation quotas are increasingly hindering conservation goals. A COFOM official noted: “many ejidos simply don't have enough space to plant the trees they are given", which oftentimes results in careless planting or even dumping of trees. In this regard, an interviewee in Senguio emphasised: "I have seen guys that plant 5 or 6 little trees in one hole. Of course they all died." 


\section{Discussion}

Over the past two decades, the temperate forests surrounding the Monarch Butterfly

Biosphere Reserve in central Mexico have shown ecological resilience. Yet the speed of forest recovery is slowing down. The overwhelming majority of the observed forest recovery was observed in the pre-2000 period, contradicting what one might expect from a forest transition theory. Our results suggest that forest transitions are uneven and unbalanced.

As elsewhere around the world, the secondary forest growth we observe is a combination of both active and passive reforestation. After systematically reviewing three decades of forest recovery data, we find that plot size and prior land-use are useful indicators to help distinguish active and passive reforestation. Large plots are more likely to be the result of passive restoration, while active reforestation was observed on accessible plots of relative small size ( $<10$ ha) that were mostly former agricultural parcels.

We observe most forest recovery on degraded forest, not on abandoned agricultural lands. This contradicts the dominant narrative in the region, and often in the literature, in which agricultural abandonment is described as the primary driver of forest recovery (Bonilla-Moheno et al. 2012; Crk et al. 2009). Nevertheless, our interviews with forest owners suggest that many hold onto the idea that agricultural abandonment is driving forest recovery. Given the generational changes and growing disinterest in the pursuit of subsistence agriculture, agricultural abandonment can potentially gain importance in the near future, but focusing on reforesting agricultural lands remains questionable if the greatest potential for recovered forests is on degraded forests. It is also notable that no reforestation is observed on barren lands. The absence of active or passive reforestation on these sites suggests that carefully conceptualized efforts might be well targeted there.

We are unable to provide any conclusive evidence about the impact of migration on forest recovery. Forest owners cited migration as an important factor driving agricultural 
abandonment in general, but could only identify eight specific plots, or only 77 ha, in which the recovery of a forest plot could specifically be attributed to migration. The intensification of outward migration coincides with the period of highest forest recovery rates, which suggests that migration is an important driver of natural regrowth. On the other hand, those most likely to migrate are landless farmers or comuneros, without political rights or rights to forest resources. Therefore, who migrates matters, and the migration of the landless may not alter successional processes if the forest users still remain. Nevertheless, it cannot be ruled out that migration of landless residents contributes to forest recovery, if their absence relieves pressure on forest resources. A more careful analysis of the relationship between migration, agricultural abandonment and forest recovery would be particularly useful.

In addition, our results suggest a need to re-examine fire dynamics in our study area, where misconceptions remain about the role of fire in the temperate ecosystem (MartínezTorres et al. 2016). We find substantial recovery over large areas recovering from a fire event. While formally, recovery in post-fire areas is a fundamentally different process than recovery in agricultural areas, we feel it is important to study this process separately. Natural conifer regrowth on sites that experienced high-severity fire is generally abundant, suggesting that post-fire active reforestation measures might be unnecessary (Donato et al. 2006).

While we did not set out to examine the effectiveness of reforestation programs, our results are discouraging for reforestation efforts. The reforestation programs in the region share many features of large conservation programs, which tend to be overly ambitious, poorly designed or neglect to consider the long-term pressures or local development aspirations (Sayer et al. 2008). And despite the poor reputation of active restoration programs among forest communities, this appears to do little to limit the popularity of reforestation programs among land-owners and institutional funders. Each interviewee reported the presence of active reforestation programs within their community. The importance of 
distinguishing between reforestation effort and reforestation success becomes more evident when reviewing official reforestation data. The National Forestry Commission (CONAFOR) and the Forestry Commission of Michoacán (COFOM) estimate their impact by assuming a relationship between the number of planted trees and surface area. This estimate is based on the number of trees that are supplied to communities within a year, yet officials recognize that no follow-up measures are in place.

The large proportion of forests recovered through successional processes indicates that temperate forests in high elevation tropical latitudes are resilient and can recover quickly. Yet counter-intuitively, this encouraging result may not be well received by policy makers and reforestation advocates if it highlights the relative difficulties of mimicking natural succession through active reforestation programs.

From the perspective of national forest officials, one can understand why more attention and research is focused on forest loss, rather than forest recovery. Countries have a disincentive to quantify forest recovery or recognize that they are in a forest transition, since they may not receive as many benefits from REDD for recovered forests as possibly envisaged. Countries that acknowledge that they are in a forest transition, and that natural forest recovery is the dominant process by which forests are being recovered, risk losing a share of international aid money to support their reforestation and conservation programs. Looking ahead, new climate conditions will influence both the rates of forest recovery and land use decisions by farmers.

Finally, our results invite us to reflect on the relative impact of our existing reforestation efforts. Since the vast majority of forest recovery can be attributed to natural regrowth, this raises questions about the cost-effectiveness of active reforestation programs as they are currently designed. Our findings are consistent with those who argue for the need to evaluate whether ecological restoration attempts are warranted (Johnson et al. 2017) and we 
concur with recent calls for forest landscape restoration that harnesses the potential of natural processes to achieve ambitious restoration targets (Chazdon \& Guariguata, 2016). Forest restoration programs might consider supporting, facilitating or accelerating natural regrowth instead of planting new seedlings. In addition, successful restoration will be the result of collaboration with local landowners to develop management programs that provide them with financial and livelihood incentives to maintain a healthy and diverse forest. Active reforestation is certainly justified in many instances, but the site conditions should be evaluated carefully. Using our knowledge about the drivers of natural regrowth may help design policy measures that may leverage existing forest resilience so that recovery can reach its full potential.

\section{Acknowledgments}

The authors are grateful to the individuals interviewed and for the knowledge they shared with this research project. We also thank Jairo López and Fredy López for assistance during the fieldwork in Mexico. This research was supported with research funds from the University of British Columbia, the National Autonomous University of Mexico (DGAPA-PAPIIT IN301215) and the Universitat Autònoma de Barcelona. EC acknowledges the financial support of the UABBanco de Santander Talent Retention Programme and notes that this work contributes to ICTAUAB "Unit of Excellence" (MinECo, MDM2015-0552). Lastly, we are grateful to the anonymous reviewers who provided constructive comments on earlier versions of the manuscript. 


\section{Literature Cited}

Aide TM, Clark ML, Grau HR, López-Carr D, Levy MA, Redo D, Bonilla-Moheno M, Riner G, Andrade-Núñez MJ, Muñiz M (2013) Deforestation and reforestation of Latin America and the Caribbean (2001-2010). Biotropica 45:262-271

Barbier EB, Burgess JC, Grainger A (2010) The forest transition: towards a more comprehensive theoretical framework. Land Use Policy 27:98-107

Bonilla-Moheno M, Aide TM, Clark ML (2012) The influence of socioeconomic, environmental, and demographic factors on municipality-scale land-cover change in Mexico. Regional Environmental Change 12:543-557

Brower LP (1996) Monarch butterfly orientation: missing pieces of a magnificent puzzle. Journal of Experimental Biology 199:93-103

Brower LP, Castilleja G, Peralta A, López-García J, Bojórquez-Tapia L, Díaz S, Melgarejo D, Missrie M (2002) Quantitative changes in forest quality in a principal overwintering area of the Monarch Butterfly in Mexico, 1971-1999. Conservation Biology 16:346359

Chazdon RL (2008) Beyond deforestation: restoring forests and ecosystem services on degraded lands. Science 320:1458-1460

Crk T, Uriarte M, Corsi F, Flynn D (2009) Forest recovery in a tropical landscape: what is the relative importance of biophysical, socioeconomic, and landscape variables? Landscape Ecology 24:629-642

EIB (2012) Forestry and Climate Change. European Investment Bank, Luxembourg http://bookshop.europa.eu/en/the-european-investment-bank-forestry-and-climatechange-pbQH3112598/

Espinosa Uranga MA (2006) Evaluación del crecimiento de tres especies de árboles de navidad y análisis de sus costos de producción. Thesis, Universidad Autónoma del Estado de Hidalgo, Mexico

FAO (2013) Guide for country reporting for FRA 2015. UN Food and Agriculture Organization, Rome http://www.fao.org/3/a-au190e.pdf

García J, Ortega O (2015) Desenvolvimiento económico y migración en Michoacán, 19802010. Cimexus 7:41-63

González Méndez M, Cruz Cobos F, Quiñonez Barraza G, Vargas Larreta B, Nájera Luna JA (2016) Dominant height growth model for Pinus pseudostrobus Lindl. In Guerrero state. Revista Mexicana de Ciencias Forestales 37: 7-20.

Hansen MC, Potapov PV, Moore R, Hancher M., Turubanova SA, Tyukavina A et al. (2013) High-Resolution global maps of 21st-century forest cover change. Science 342:850853

Honey-Rosés J (2009) Disentangling the proximate factors of deforestation: the case of the Monarch Butterfly Biosphere Reserve in Mexico. Land Degradation \& Development 20:22-32

Honey-Rosés J, Baylis K, Ramírez MI (2011) A spatially explicit estimate of avoided forest loss: spatial estimate of avoided forest loss. Conservation Biology 25:1032-1043

Honey-Rosés J, López-García J, Rendón-Salinas E, Peralta-Higuera A, Galindo-Leal C (2009) To pay or not to pay? Monitoring performance and enforcing conditionality when paying for forest conservation in Mexico. Environmental Conservation 36:120-128

Howard BC (2016) India plants 50 million trees in one day, smashing world record. http://news.nationalgeographic.com/2016/07/india-plants-50-million-trees-uttarpradesh-reforestation/ (accessed September 1, 2016). 
Johnson CR, Chabot RH, Marzloff MP, Wotherspoon S (2017) Knowing when (not) to attempt ecological restoration: when (not) to restore ecosystems. Restoration Ecology 25:140-147

Keenan RJ, Reams GA, Achard F, de Freitas JV, Grainger A, Lindquist E (2015) Dynamics of global forest area: results from the FAO Global Forest Resources Assessment 2015. Forest Ecology and Management 352:9-20

Klooster D (2003) Forest transitions in Mexico: institutions and forests in a globalized countryside. The Professional Geographer 55:227-237

Köhl M, Lasco R, Cifuentes M, Jonsson Ö, Korhonen KT, Mundhenk P, de Jesus Navar J, Stinson G (2015) Changes in forest production, biomass and carbon: results from the 2015 UN FAO Global Forest Resource Assessment. Forest Ecology and Management 352:21-34

Lamb D, Erskine PD, Parrotta JA (2005) Restoration of degraded tropical forest landscapes. Science 310:1628-1632

Lara-González R, Sánchez-Velásquez LR. Corral-Aguirre J (2009) Regeneration of Abies religiosa in canopy gaps versus understory, Cofre de Perote National Park, México. Agrociencia 43(7): 739-747

Le HD, Smith C, Herbohn J, Harrison S (2012) More than just trees: assessing reforestation success in tropical developing countries. Journal of Rural Studies 28:5-19

Lomelí Jiménez, AJ, Pérez-Salicrup DR, Figueroa Rangel BL, Mendoza-Cantú ME, Cuevas Guzmán R, Andresen E, Morfín Ríos JE (2017) Are Changes in Remotely Sensed Canopy Cover Associated to Changes in Vegetation Structure, Diversity, and Composition in Recovered Tropical Shrublands? Plant Ecology 218(8): 1021-33

López E, Bocco G, Mendoza M, Velázquez A, Rogelio Aguirre-Rivera J (2006) Peasant emigration and land-use change at the watershed level: a GIS-based approach in Central Mexico. Agricultural Systems 90:62-78

Martínez-Torres HL, Castillo A, Ramírez MI, Pérez-Salicrup DR (2016) The importance of the traditional fire knowledge system in a subtropical montane socio-ecosystem in a protected natural area. International Journal of Wildland Fire 25:911-921

Mather AS (1992) The forest transition. Area 367-379

Maurer M (2016) Where did that forest come from? Assessing the drivers of active reforestation and natural regeneration. MSc Thesis, Universitat Autònoma de Barcelona, Bellaterra, Spain

Meyfroidt P, Lambin EF (2011) Global forest transition: prospects for an end to deforestation. Annual Review of Environment and Resources 36:343-371

Nagendra H (2007) Drivers of reforestation in human-dominated forests. Proceedings of the National Academy of Sciences 104:15218-15223

Nagendra H (2008) Do parks work? Impact of protected areas on land cover clearing. AMBIO: a Journal of the Human Environment 37:330-337

Navarrete JL, Isabel Ramírez M, Pérez-Salicrup DR (2011) Logging within protected areas: spatial evaluation of the Monarch Butterfly Biosphere Reserve, Mexico. Forest Ecology and Management 262:646-654

Payn T, Carnus JM, Freer-Smith P, Kimberley M, Kollert W, Liu S, Orazio C, Rodriguez L, Silva LN, Wingfield MJ (2015) Changes in planted forests and future global implications. Forest Ecology and Management 352:57-67

Ramírez MI, Azcarate JG, Luna L (2003) Effects of human activities on Monarch Butterfly habitat in protected mountain forests, Mexico. The Forestry Chronicle 79:242-246

Ramírez MI, Miranda R, Zubieta R, Jiménez M (2006) Land cover and road network map for the Monarch Butterfly Biosphere Reserve in Mexico, 2003. Journal of Maps 3:181190 
Ramírez MI, Sáenz-Romero C, Rehfeldt G, Salas-Canela L (2015) Threats to the availability of overwintering habitat in the Monarch Butterfly Biosphere Reserve. Pages 157-168 In: Monarchs in a changing world: biology and conservation of an iconic butterfly. Cornell University Press, Ithaca, USA

Rudel TK, Coomes OT, Moran E, Achard F, Angelsen A, Xu J, Lambin E (2005) Forest transitions: towards a global understanding of land use change. Global Environmental Change 15:23-31

Sayer J, Bullb G, Elliottc C (2008) Mediating forest transitions: 'Grand design' or 'Muddling through'. Conservation and Society 6(4):320-327

Schroeder H, McDermott C (2014) Beyond carbon: enabling justice and equity in REDD+ across levels of governance. Ecology and Society 19 (1):31

SEMARNAT (2011) Apoyos CONAFOR - Reserva de la Biosfera Mariposa Monarca. SEMARNAT

Sitzia T, Semenzato P, Trentanovi G (2010) Natural reforestation is changing spatial patterns of rural mountain and hill landscapes: a global overview. Forest Ecology and Management 259:1354-1362

Timms BF, Hayes J, McCracken M (2013) From deforestation to reforestation: applying the forest transition to the Cockpit Country of Jamaica: from deforestation to reforestation. Area 45:77-87

Trac CJ, Harrell S, Hinckley TM, Henck AC (2007) Reforestation programs in Southwest China: reported success, observed failure, and the reasons why. Journal of Mountain Science 4:275-292

Trumbore S, Brando P, Hartmann H (2015) Forest health and global change. Science 349:814-818

Tucker CM (2004) Community institutions and forest management in Mexico's Monarch Butterfly Reserve. Society \& Natural Resources 17:569 - 587

Van Den Hoek J, Ozdogan M, Burnicki A, Zhu AX (2014) Evaluating forest policy implementation effectiveness with a cross-scale remote sensing analysis in a priority conservation area of Southwest China. Applied Geography 47:177-189

Venegas Pérez Y, Rodríguez S, López DT (2011) Análisis base para el diseño de la estrategia de reforestación de la Reserva de la Biosfera Mariposa Monarca. Monarch Butterfly Fund. Dirección de la Reserva de la Biosfera Mariposa Monarca, Michoacán, México

Verdone M, Seidl A (2017) Time, space, place, and the Bonn Challenge global forest restoration target: Bonn Challenge global forest restoration target. Restoration Ecology 25:903-911

Vidal O, López-García J, Rendón-Salinas E (2014) Trends in deforestation and forest degradation after a decade of monitoring in the Monarch Butterfly Biosphere Reserve in Mexico: Monarch Butterflies in the biosphere reserve. Conservation Biology 28:177-186

Walsh SJ, Shao Y, Mena CF, McCleary AL (2008) Integration of Hyperion satellite data and a household social survey to characterize the causes and consequences of reforestation patterns in the northern Ecuadorian Amazon. Photogrammetric Engineering \& Remote Sensing 74:725-735

Yackulic CB, Fagan M, Jain M, Jina A, Lim Y, Marlier M, Muscarella R, Adame P, DeFries R, Uriarte M (2011) Biophysical and socioeconomic factors associated with forest transitions at multiple spatial and temporal scales. Ecology and Society 16 (3):15 
Table 1 Sampled forest plots by time period and recovery type in hectares (n plots). Natural Active Mix Total

\begin{tabular}{lcccc} 
& Regrowth & Reforestation & & \\
\cline { 2 - 4 } $1986-1993$ & 431.4 & - & 121.2 & 552.6 \\
$1993-2000$ & $(12)$ & & $(5)$ & \\
& 93.7 & 23.6 & 45.9 & 163.2 \\
$2000-2003$ & $(12)$ & $(4)$ & $(2)$ & \\
& 20.3 & - & - & 20.3 \\
$2003-2006$ & $(1)$ & & & \\
& 11.8 & 4.4 & 26.3 & 42.5 \\
$2006-2009$ & $(1)$ & $(1)$ & $(3)$ & \\
& 8.9 & 2 & - & 10.9 \\
\hline Total (ha) & $(2)$ & $(1)$ & & 789.5 \\
(n) & 566.1 & 30 & 193.4 & \\
\hline$\%$ & $(28)$ & $(6)$ & $(10)$ & 100 \\
\hline
\end{tabular}


Table 2 Results from the ordinal logistic model for reforestation type: passive, mixed and active

\begin{tabular}{llll} 
Explanatory Variable & Coefficient & Std. Error & p value \\
\hline $\begin{array}{l}\text { Plot size } \\
\text { Protection status (reference condition: buffer) }\end{array}$ & 0.03 & 0.03 & 0.262 \\
$\quad$ core & 1.29 & 1.99 & 0.517 \\
$\quad$ outside & 0.33 & 1.10 & 0.761 \\
$\begin{array}{l}\text { Prior land use (reference condition: agriculture) } \\
\text { barren }\end{array}$ & -0.86 & 1.72 & 0.617 \\
$\quad$ degraded*** & $\mathbf{1 9 . 4 7}$ & $\mathbf{1 . 2 2 e - 0 7}$ & $\mathbf{0 . 0 0 0}$ \\
$\quad$ degraded forest and agriculture & -0.37 & 0.96 & 0.701 \\
$\quad$ degraded forest and grazing & 1.94 & 1.28 & 0.128 \\
$\quad$ forest fire & -0.36 & 1.26 & 0.776 \\
& & & \\
Intercepts & & & \\
active|mixed & & & \\
mixed|passive & -0.62 & 1.05 & 0.558 \\
Residual Deviance & 1.09 & & \\
AIC & & & \\
$* * *$ p $<0.005$ & 57.16 & &
\end{tabular}


Table 3 Forest Recovery Type by Driver in hectares (n plots)

\begin{tabular}{lccccc} 
& $\begin{array}{c}\text { Agricultural } \\
\text { Abandonment }\end{array}$ & $\begin{array}{c}\text { Reduced } \\
\text { Grazing }\end{array}$ & $\begin{array}{c}\text { Reduced } \\
\text { Logging }\end{array}$ & $\begin{array}{c}\text { Post-fire } \\
\text { recovery }\end{array}$ & Unidentified \\
\cline { 2 - 6 } Passive & 53.8 & 195 & 164.3 & 148.5 & 4.5 \\
Reforestation & $(6)$ & $(7)$ & $(11)$ & $(3)$ & $(1)$ \\
Active & 28 & & & 2 & \\
Reforestation & $(5)$ & & & $(1)$ & \\
Mixed & 127.5 & & 33.9 & 32 \\
& $(6)$ & & & $(2)$ & $(2)$ \\
\hline Total (ha) & 209.3 & 195 & 164.3 & 184.4 & 36.5 \\
(n) & $(17)$ & $(7)$ & $(11)$ & $(6)$ & $(3)$ \\
\hline$\%$ & 26.5 & 24.7 & 20.8 & 23.4 & 4.6 \\
\hline
\end{tabular}




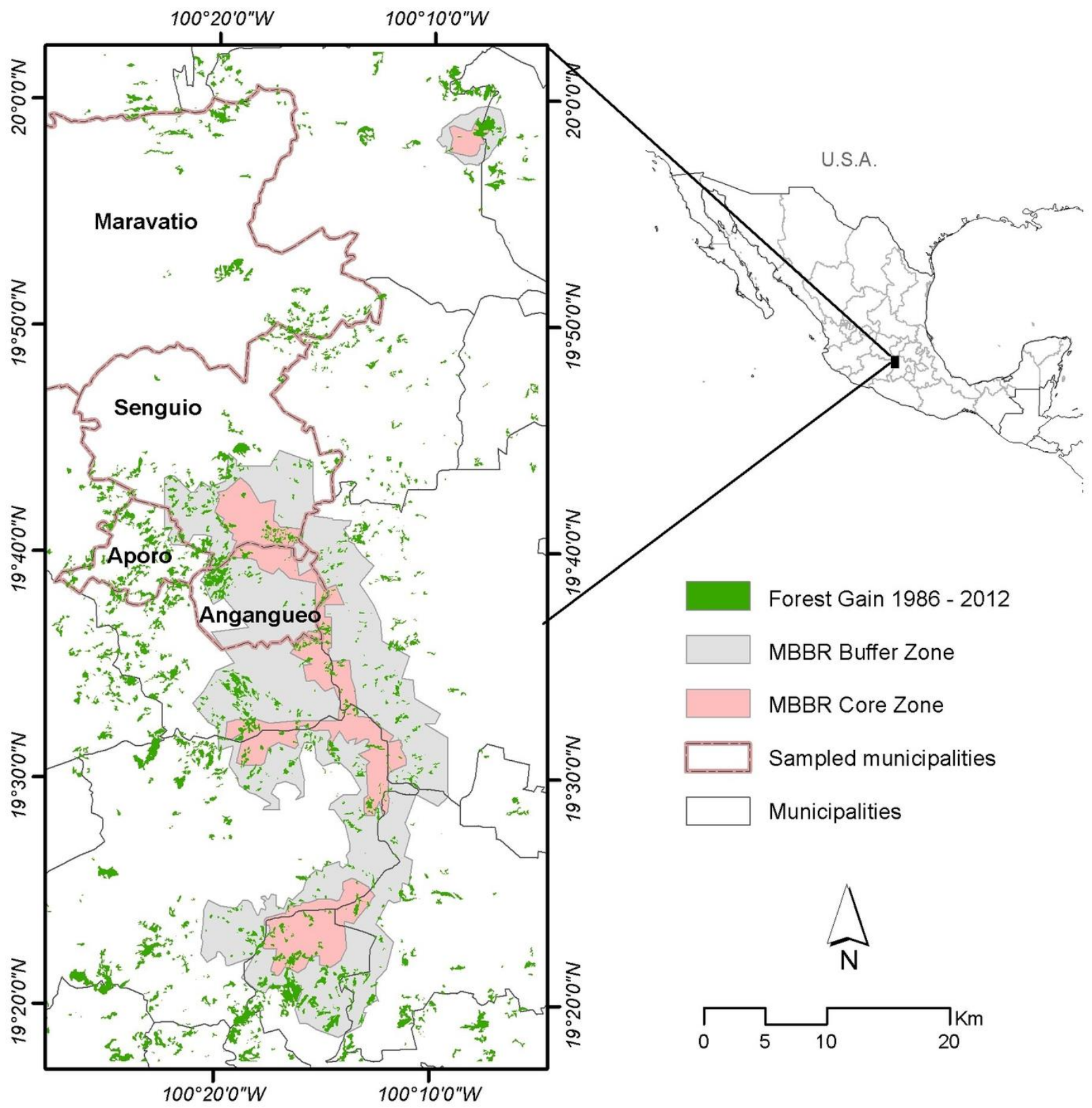

Figure 1. The study area examined the region surrounding the Monarch Butterfly Biosphere Reserve in central Mexico. The figure identifies the sampled municipalities and the forest plots with regrowth in the period 1986-2012. 


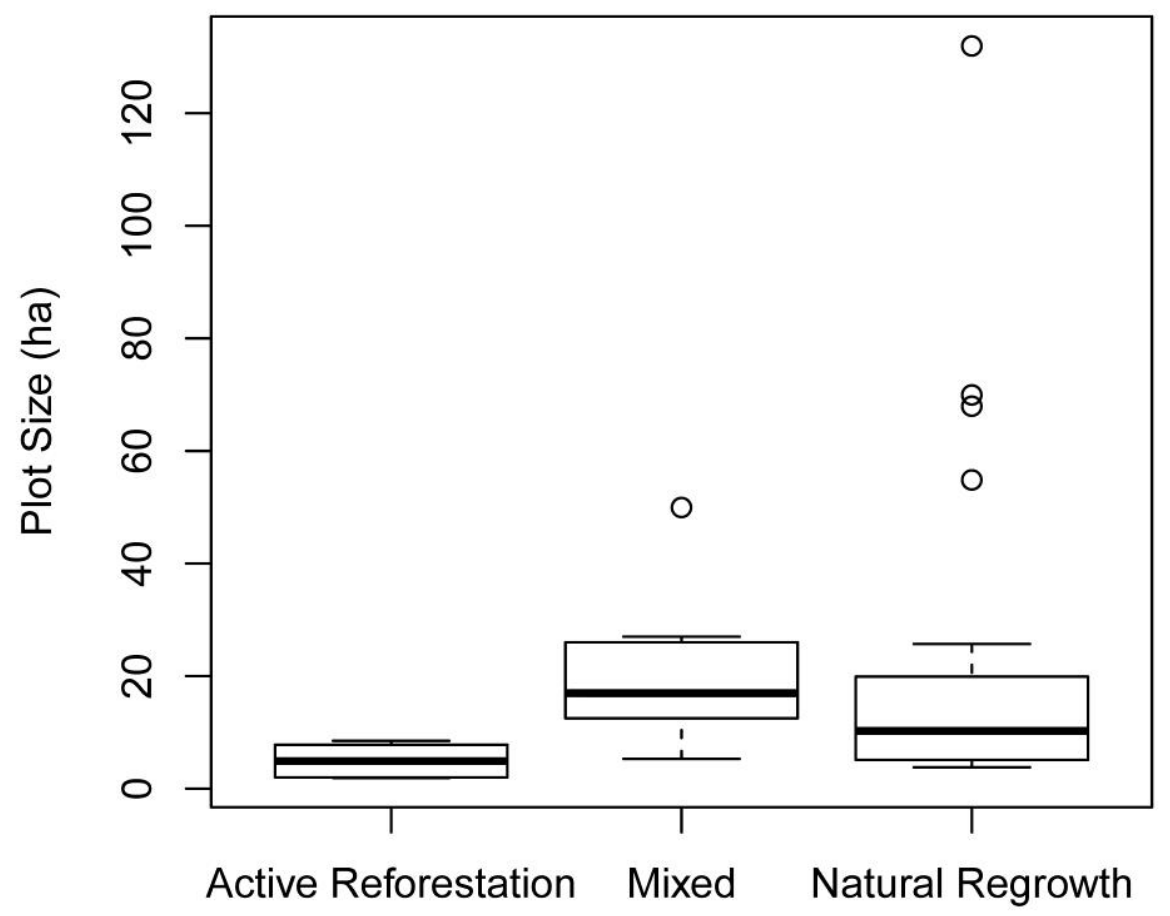

Figure 2. Forest recovery type by plot size.

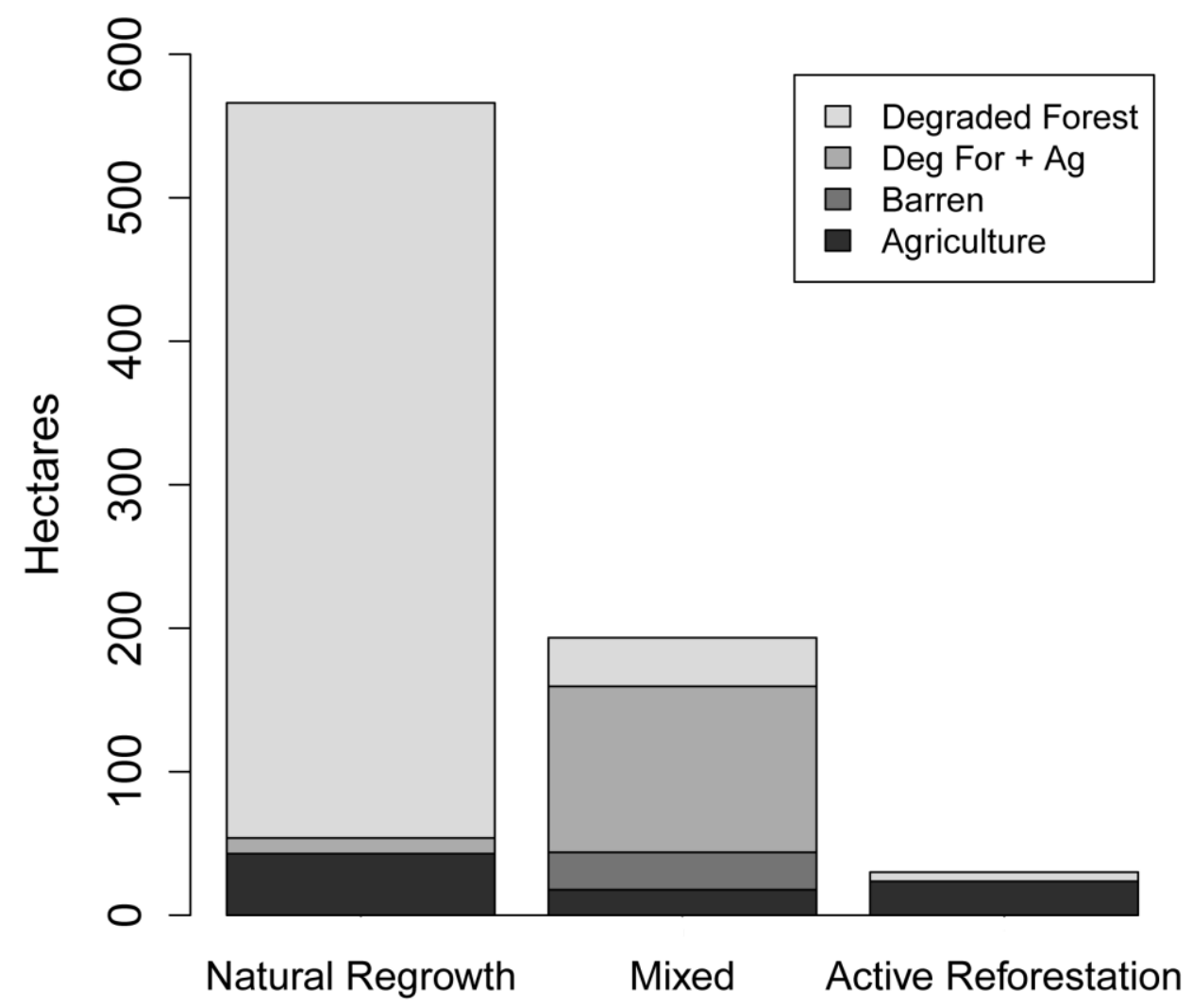

Figure 3 . Forest recovery type by prior land use. 